\title{
NASA head fends off proposal to bring in 'base closure' scheme
}

\begin{abstract}
Washington. The US National Aeronautics and Space Administration (NASA) is unlikely to meet its ambitious goals for cutting back on facilities and personnel to meet future budget predictions, due partly to internal 'turf battles' and partly to outside political pressure, according to a report released last week by the congressional General Accounting Office (GAO).

In fact, says GAO, NASA may eventually need an independent base-closure commission, similar to one that reviewed military bases, to help it to decide where politically sensitive cuts should be made.

The report points out that NASA's efforts to cut $\$ 4$ billion - or 25 per cent of its facility costs - by 2000 , and to trim its
\end{abstract}

21,500-person workforce by nearly 20 per cent, have run into a number of problems. First is the agency's own problem in accurately predicting cost reductions. In some cases, NASA has overestimated how much money could be saved by a certain action, such as moving all the agency's research aircraft to California's Dryden Flight Research Center (see Nature 382, 745; 1996).

Plans to consolidate telecommunications and supercomputing capabilities have suffered from flawed or incomplete analysis. And attempts to find savings by cost-sharing with the Defense Department (DOD) have met with little success: "Each NASA and DOD centre or laboratory wants to protect its ability to maintain technical expertise and

\section{Paris plan prefers art to anthropology}

Paris. Art scored a victory over science last week when a commission set up by Jacques Chirac, the French president, recommended that the world's largest anthropology museum, the Musée de l'Homme (Museum of Mankind) in Paris, should be turned into a museum of primitive art. In doing so, it rejected a alternative proposal from researchers to renovate the existing museum and create a 'Grand Musée d'Histoire Naturelle de l'Homme'.

The latter proposal, which was put forward by Henry de Lumley, the director of the museum's parent body, the Natural History Museum (NHM), and a member of the commission, would draw together research on man's social, cultural and biological evolution and provide imaginative presentations of the museum's 735,000 objects (see Nature 383, 109; 1996).

But at a press conference in Paris last Friday, 13 September, the 'commission of early art', set up by Chirac earlier this year, recommended that the museum's collections merge with those of the Museum of African and Oceanic Arts within a new 'Museum of Mankind, Art and Civilization'. The project is estimated to cost FFr 1 billion (US $\$ 200$ million) over five years, according to Jacques Friedmann, the chairman of the commission and chief executive office of UAP, a French insurance company.

Under the scheme, the Natural History Museum would lose control of the reorganized museum. Moreover, the latter would no longer be under only the ministry of education and research, but would also be the responsibility of the Ministry of Culture. The NHM would also lose its laboratory of ethnology to the new institution.

Friedmann says that most members of the commission felt that the concept of the new museum breaks down the barrier between art and science. But although science is mentioned occasionally in the scheme, what it proposes amounts essentially to a museum of 'beaux arts'. As such, it has been unanimously condemned by

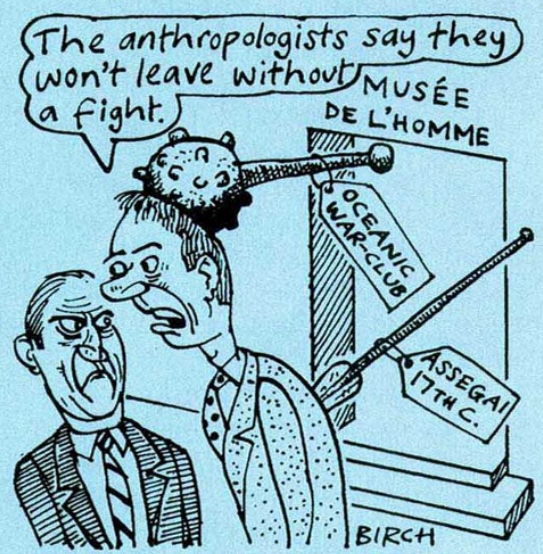

museum staff, who characterize the scheme as a hostile takeover bid of a scientific museum by art specialists.

De Lumley points out that the final decision rests with Chirac, and that the museum will continue to fight for its proposal.

Declan Butler competence," says GAO.

More fundamental, however, are the political problems of 'downsizing'. A proposal from NASA earlier this year to reduce dramatically the number of personnel at its headquarters received an angry response from members of Congress in the Washington area, and the cuts are now expected to be less severe. The plan to shift aircraft to Dryden prompted congressional delegations representing other NASA centres to write to the NASA administrator, Dan Goldin, earlier this month to "express their concern".

According to the GAO report, NASA's own efforts to close facilities or relocate activities have "been slowed by parochial concerns about the effects of such actions on missions, personnel, and local communities". As a result, it says, NASA "may not be able to successfully downsize infrastructure, especially facilities, on its own".

A neutral closure commission has therefore been proposed, which would provide political cover for any hard decisions. It was NASA and DOD officials who suggested the idea to GAO, according to Thomas Schulz, the study's lead auditor.

But Goldin, who has built a reputation as a reformer, last week told the House of Representatives government reform committee that he would rather handle the problem internally. A closure commission, he said, would "destroy NASA".

Congress would have to decide whether such an extreme measure as a closure commission is necessary. The White House science office is expected to come out with its own progress report on federal laboratory downsizing next month, updating a report released last year. That report, say White House officials, is likely to be more optimistic about how much progress NASA has made in its downsizing.

If the space agency is struggling with cost reductions, the White House should bear some of the blame. NASA - like other federal agencies - is uncertain how much money it will have to spend in 2000 . The Clinton administration, trying to show its budget-cutting zeal to the Republicancontrolled Congress earlier this year, released projections showing NASA's budget falling from just under $\$ 14$ billion in 1997 to $\$ 11.6$ billion in 2000 . But Goldin (and others in the administration) have repeatedly said those figures are not firm. As a result, NASA has no idea what budgetary target it needs to hit, and therefore how much it needs to cut.

Tony Reichhardt 